\title{
Pseudomonas duriflava sp. nov., isolated from a desert soil
}

Correspondence
Ren Lai
rlai72@njau.edu.cn

\author{
Rui Liu, ${ }^{1} \dagger$ Huan Liu, ${ }^{2,3}$ † Hao Feng, ${ }^{1}$ Xu Wang, ${ }^{1}$ Chong-Xing Zhang, ${ }^{1}$ \\ Ke-Yun Zhang ${ }^{1}$ and Ren Lai ${ }^{1,2}$
}

${ }^{1}$ Key Laboratory of Microbiological Engineering of Agricultural Environment, Ministry of Agriculture, Life Sciences College of Nanjing Agricultural University, Nanjing, Jiangsu 210095, PR China

${ }^{2}$ Biotoxin Department of Key Laboratory of Animal Models and Human Disease Mechanisms, Kunming Institute of Zoology, Chinese Academy of Sciences, Kunming, Yunnan 650223, PR China

${ }^{3}$ Graduate School of the Chinese Academy of Sciences, Beijing 100009, China
The genus Pseudomonas sensu stricto originally comprised only species belonging to Pseudomonas RNA homology group I (Palleroni, 1984) in the Gammaproteobacteria (Kersters et al., 1996). However, the genus was subdivided into two main intrageneric clusters (as reviewed by Anzai et al., 2000): the first cluster comprised six groups and the second had only one group. Pseudomonads are abundant in various environments, such as water, air and soil. In our search for organisms capable of growing in desert ecosystems, a bacterial strain, designated $\mathrm{HR}^{\mathrm{T}}$, was isolated and analysed using polyphasic taxonomy. An analysis of $16 \mathrm{~S}$ rRNA gene sequence similarities indicated that the isolate was closely related to the Pseudomonas aeruginosa/Pseudomonas stutzeri group within the first cluster and formed a distinct line. On the basis of phenotypic and genotypic evidence, it is proposed that strain $\mathrm{HR}^{\mathrm{T}}$ represents a novel species of the genus Pseudomonas.

†These authors contributed equally to this work.

The GenBank/EMBL/DDBJ accession number for the 16S rRNA gene sequence of strain $\mathrm{HR}^{\top}$ is EU046271.

Transmission electron micrographs of strain $\mathrm{HR}^{\top}$ are available as supplementary material with the online version of this paper.
Strain $\mathrm{HR} 2^{\mathrm{T}}$ was isolated from a desert soil sample by using the usual dilution plating technique on Luria-Bertani (LB) agar $\left(1^{-1}: 5 \mathrm{~g}\right.$ yeast extract, $10 \mathrm{~g}$ tryptone, $10 \mathrm{~g} \mathrm{NaCl}$, $\mathrm{pH}$ 7.0) incubated for 2 days at $30{ }^{\circ} \mathrm{C}$ under aerobic conditions. The isolate was cultivated routinely on LB agar or in LB broth at the same temperature. The strain was maintained in a glycerol suspension $(20 \%, \mathrm{v} / \mathrm{v})$ at $-70{ }^{\circ} \mathrm{C}$.

Amplification and sequencing of the 16S rRNA gene were performed according to a method described by Cui et al. (2001), but which was modified slightly by us: the primers used for the PCR amplification were $5^{\prime}$ AGAGTTTGATCCTGGCTCAG-3' (forward) and $5^{\prime}$ AAGGAGGTGATCCAAGCCGCA-3' (reverse), corresponding to positions $8-27$ and $1521-1540$, respectively, in the 16S rRNA sequence of Escherichia coli (Brosius et al., 1978). The resultant sequence (1404 bp) of strain HR2 ${ }^{\mathrm{T}}$ was compared with sequences available from the GenBank database, using a BLAST search to determine an approximate phylogenetic affiliation. Phylogenetic trees were inferred using PHYLIP (Felsenstein, 1993) and MEGA (version 3.1; Kumar et al., 2001) after multiple alignment of the data by CLUSTAL_X (Thompson et al., 1997). Distances (using distance options according to the Kimura two-parameter model; Kimura, 1980, 1983) and clustering were based on 
the neighbour-joining (Saitou \& Nei, 1987) and maximum-likelihood (Felsenstein, 1981) methods. The bootstrap resampling method of Felsenstein (1985) (1000 replicates) was used to assess the reliability of the phylogenetic trees. Comparisons of 16S rRNA gene sequences showed that strain $\mathrm{HR} 2^{\mathrm{T}}$ should be positioned within the genus Pseudomonas, being most closely related to Pseudomonas luteola IAM $13000^{\mathrm{T}}$ (97.5\% similarity); the sequence similarities with respect to type strains of other established Pseudomonas species were less than $96.4 \%$. A phylogenetic tree based on the neighbour-joining method indicated that strain $\mathrm{HR} 2^{\mathrm{T}}$ formed a monophyletic clade adjacent to $P$. luteola IAM $13000^{\mathrm{T}}$ with high bootstrap support (94\%) (Fig. 1).

Chromosomal DNA from strain $\mathrm{HR}^{\mathrm{T}}$ was extracted and purified according to the procedure of Yoon et al. (1996). The DNA G $+\mathrm{C}$ content was measured according to the method of Cashion et al. (1997) and was found to be $55.2 \mathrm{~mol} \%$. This value is slightly below the range (58$70 \mathrm{~mol} \%$ ) mentioned by Palleroni (1984) for the genus Pseudomonas and is close to that of P. luteola IAM $13000^{\mathrm{T}}$
(54.6 mol\%; data from this study). DNA-DNA hybridization between strain HR2 $2^{\mathrm{T}}$ and P. luteola IAM $13000^{\mathrm{T}}$ was measured as described by De Ley et al. (1970) with the modifications described by Huß et al. (1983) and Escara \& Hutton (1980). Renaturation rates were computed with the TRANSFER.BAS program described by Jahnke (1992). At the DNA-DNA level, there was $53.2 \%$ genetic relatedness between strain $\mathrm{HR}^{\mathrm{T}}$ and P. luteola IAM $13000^{\mathrm{T}}$; as the recommended threshold value for the delineation of genomic species is considered to be $70 \%$ DNA-DNA relatedness (Stackebrandt et al., 2002), these two strains could be confirmed as belonging to different species.

Fatty acid methyl esters were prepared and identified according to the instructions of the Microbial Identification system (MIDI), as described by Sasser (1990), from cultures of strain $\mathrm{HR} 2^{\mathrm{T}}$ grown on tryptic soy agar (Merck) for 2 days at $30{ }^{\circ} \mathrm{C}$. Type strains of the closely related species $P$. luteola (IAM $13000^{\mathrm{T}}$ ) and Pseudomonas oryzihabitans (IAM $1568^{\mathrm{T}}$ ) were also cultured under the same nutrient and temperature conditions and characterized concurrently with strain $\mathrm{HR} 2^{\mathrm{T}}$. The results of

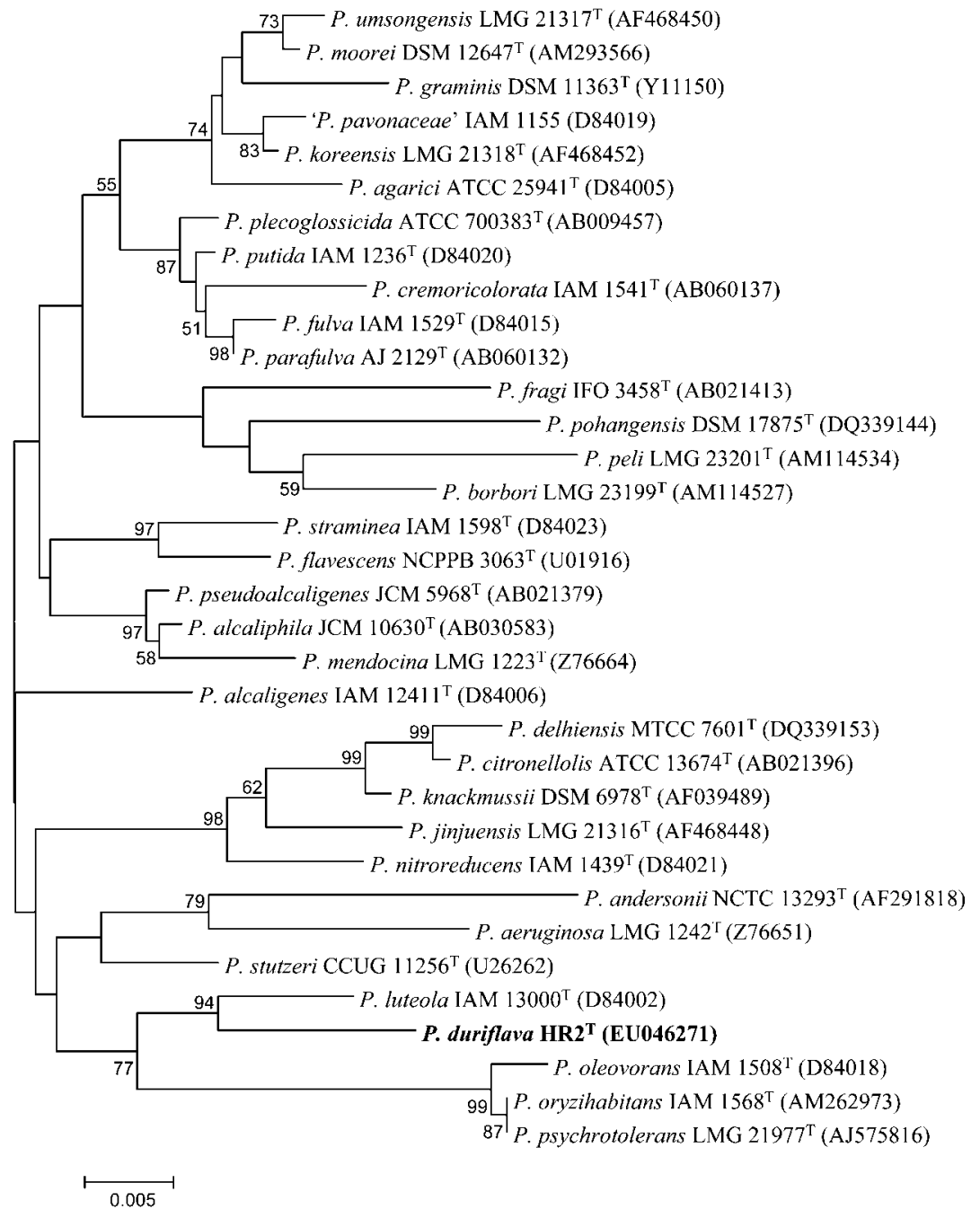

Fig. 1. Neighbour-joining phylogenetic tree, based on 16S rRNA gene sequences, showing the positions of strain $\mathrm{HR}^{\top}$ and some related Pseudomonas species. Bootstrap percentages (based on 1000 resamplings) greater than $50 \%$ are shown at nodes. The maximum-likelihood tree showed essentially the same topology (data not shown). Bar, 0.005 substitutions per nucleotide position. 
Table 1. Fatty acid content (\%) of strain $\mathrm{HR}^{\top}$ and the type strains of phylogenetically related species of the genus $P$ seudomonas

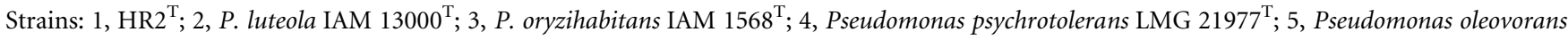
IAM $1508^{\mathrm{T}}$; 6, P. stutzeri CCUG $11256^{\mathrm{T}}$. For $1-3$, data are from this study; for 4 and 5 , data are from Hauser et al. (2004); for 6, data are from Manaia \& Moore (2002). tr, Trace $(<1.0 \%)$; - not detected.

\begin{tabular}{|c|c|c|c|c|c|c|}
\hline Fatty acid & 1 & 2 & 3 & 4 & 5 & 6 \\
\hline $10: 03-\mathrm{OH}$ & 2.1 & 2.0 & 2.8 & 2.6 & 3.3 & 3.2 \\
\hline $12: 03-\mathrm{OH}$ & 3.5 & 4.3 & 3.9 & 3.0 & 3.3 & 3.2 \\
\hline $12: 02-\mathrm{OH}$ & 0.7 & 1.5 & 2.1 & 1.8 & - & - \\
\hline $10: 0$ & 0.2 & 0.1 & - & - & 0.2 & $\operatorname{tr}$ \\
\hline $11: 0$ & - & - & - & - & 0.1 & $\operatorname{tr}$ \\
\hline $12: 0$ & 6.6 & 6.9 & 5.8 & 4.5 & 7.7 & 7.5 \\
\hline $14: 0$ & 0.8 & 1.7 & - & - & 0.2 & 1.3 \\
\hline $15: 0$ & - & - & - & - & 0.2 & $\operatorname{tr}$ \\
\hline $16: 0$ & 11.2 & 23.0 & 21.5 & 22.6 & 12.0 & 19.7 \\
\hline cyclo-17: 0 & - & - & 0.5 & - & 0.6 & $\operatorname{tr}$ \\
\hline $18: 1$ & 46.3 & 35.6 & 41.8 & 49.1 & 46.5 & 36.5 \\
\hline $18: 0$ & 0.7 & 0.6 & 0.3 & - & 0.5 & $\operatorname{tr}$ \\
\hline cyclo-19:0 $018 \mathrm{c}$ & 4.6 & 6.8 & 2.7 & - & - & $\operatorname{tr}$ \\
\hline Summed feature $3^{\star}$ & 22.8 & 15.7 & 17.1 & 16.4 & 22.9 & 27.1 \\
\hline
\end{tabular}

${ }^{\star} 16: 1 \omega 7 c$ and/or iso- $15: 02-\mathrm{OH}$.

the chemotaxonomic analyses are given in Table 1; all of the strains were shown to have rather similar fatty acid profiles. The presence of high levels of $18: 1$, summed feature 3 and $16: 0$, along with $10: 03-\mathrm{OH}, 12: 03-\mathrm{OH}$ and 12:0 2-OH, supported the view that strain HR2 ${ }^{\mathrm{T}}$ belonged to the genus Pseudomonas (Oyaizu \& Komagata, 1983).

Cell morphology and motility were examined using light microscopy (model BH 2; Olympus) and transmission electron microscopy (model H-7650; Hitachi) after $48 \mathrm{~h}$ growth on LB agar at $30{ }^{\circ} \mathrm{C}$. For the transmission electron microscopy observations, cells were negatively stained with $1 \% \quad(w / v)$ phosphotungstic acid and air-dried (see Supplementary Fig. S1 available in IJSEM Online). Gramstaining and endospore formation were investigated according to the methods described by Smibert \& Krieg (1994). Growth at different temperatures and $\mathrm{pH}$ values was investigated as described by Xu et al. (2005), using LB as the basal medium. $\mathrm{NaCl}$ tolerance was tested using $\mathrm{LB}$ broth supplemented with $0,1,2,3,4$ or $5 \%(\mathrm{w} / \mathrm{v}) \mathrm{NaCl}$. Growth was tested on nutrient agar, Simmons' citrate agar and MacConkey agar. The production of fluorescent pigment was tested on King's medium B (King et al., 1954). Oxidase, catalase and phenylalanine deaminase activities and the hydrolysis of casein, gelatin, Tweens 80 and 20, aesculin, DNA, starch and carboxymethylcellulose were investigated as described by Smibert \& Krieg (1994). Acid production from carbohydrates was determined using the medium and method described by Yamaguchi \& Yokoe (2000). Studies designed to determine the utilization of substrates as single carbon sources were carried out as described by Zhou et al. (2007). Sensitivity to antibiotics was tested using the diffusion method, as described by Park et al. (2007), on LB agar at $30{ }^{\circ} \mathrm{C}$ with filter-paper discs
(8 mm diameter; Sanofi Pasteur) containing the following antibiotics: streptomycin $(10 \mu \mathrm{g})$, penicillin $\mathrm{G}$ (10 IU), ampicillin $(10 \mu \mathrm{g})$, chloramphenicol $(30 \mu \mathrm{g})$, erythromycin $(15 \mu \mathrm{g})$, tetracycline $(30 \mu \mathrm{g})$, ofloxacin $(5 \mu \mathrm{g})$, amoxicillin $(10 \mu \mathrm{g})$, cefamezin $(30 \mu \mathrm{g})$, rifampicin $(5 \mu \mathrm{g})$, gentamicin $(10 \mu \mathrm{g})$, ceftazidime $(30 \mu \mathrm{g})$, vancomycin $(30 \mu \mathrm{g})$, kanamycin $(30 \mu \mathrm{g})$, carbenicillin $(100 \mu \mathrm{g})$ and polymyxin $\mathrm{B}$ $(30 \mu \mathrm{g})$. All tests were performed at $30{ }^{\circ} \mathrm{C}$ and properties were recorded after 2 days. Additional biochemical features were tested using API 20E kits according to the instructions of the manufacturer (bioMérieux). P. luteola IAM $13000^{\mathrm{T}}$ and $P$. oryzihabitans IAM $1568^{\mathrm{T}}$ were included in these studies and analysed under the same conditions. Phenotypic characteristics of strain $\mathrm{HR} 2^{\mathrm{T}}$ are given in the species description and in Table 2. As shown in Table 2, our isolate can be readily differentiated from its closest phylogenetic relatives in the genus Pseudomonas sensu stricto on the basis of several phenotypic properties.

The data presented indicate that strain $\mathrm{HR}_{2}{ }^{\mathrm{T}}$ is distinguishable from all recognized species of the genus Pseudomonas. Thus $\mathrm{HR}^{\mathrm{T}}$ represents a novel species of the genus Pseudomonas, for which the name Pseudomonas duriflava sp. nov. is proposed.

\section{Description of Pseudomonas duriflava sp. nov.}

Pseudomonas duriflava (du.ri.fla'va. L. adj. durus hard; L. adj. flavus yellow; N.L. fem. adj. duriflava hard yellow).

Cells are Gram-negative, non-motile, non-spore-forming, round-ended, aerobic rods approximately 0.6-0.8 $\times 0.7-$ $1.1 \mu \mathrm{m}$ in size. Colonies on LB agar are dry, yellow, circular, convex, translucent, hard, wrinkled and approximately $1.0-2.5 \mathrm{~mm}$ in diameter within 2 days at $30{ }^{\circ} \mathrm{C}$. 
Table 2. Distinctive phenotypic characteristics of strain $\mathrm{HR} 2^{\top}$ and related Pseudomonas species

Strains: 1 , HR2 $2^{\mathrm{T}} ; 2$, P. luteola IAM $13000^{\mathrm{T}} ; 3$, P. oryzihabitans IAM $1568^{\mathrm{T}}$; 4, Pseudomonas psychrotolerans LMG $21977^{\mathrm{T}}$; 5 , Pseudomonas oleovorans IAM $1508^{\mathrm{T}} ; 6$, P. stutzeri CCUG $11256^{\mathrm{T}}$. For $1-3$, data are from this study; for 4, data are from Hauser et al. (2004). +, Positive; - , negative; $d$, reaction differs between strains; ND, not determined.

\begin{tabular}{|c|c|c|c|c|c|c|}
\hline Characteristic & 1 & 2 & 3 & 4 & 5 & 6 \\
\hline Yellow pigment & + & + & + & + & $-*$ & $d \neq$ \\
\hline \multicolumn{7}{|l|}{ Growth at: } \\
\hline $4{ }^{\circ} \mathrm{C}$ & - & - & + & + & $-*$ & -末 \\
\hline $42{ }^{\circ} \mathrm{C}$ & + & + & - & - & $+^{*}$ & ND \\
\hline Tolerance of $5 \% \mathrm{NaCl}$ & - & + & + & + & $+^{*}$ & $+\$$ \\
\hline Nitrate reduction & - & + & - & $\mathrm{ND}$ & $\mathrm{ND}$ & $+\S$ \\
\hline \multicolumn{7}{|l|}{ Hydrolysis of: } \\
\hline Gelatin & - & + & + & $\mathrm{ND}$ & $-\dagger$ & $-\ddagger$ \\
\hline Starch & + & - & - & $\mathrm{ND}$ & $+\dagger$ & $+f$ \\
\hline Tween 80 & + & + & + & ND & $-\dagger$ & $+\ddagger$ \\
\hline Aesculin & + & + & - & - & $-*$ & ND \\
\hline \multicolumn{7}{|l|}{ Acid production from: } \\
\hline D-Xylose & + & + & + & + & $-{ }^{*}$ & ND \\
\hline D-Mannose & - & + & + & + & $-{ }^{*}$ & ND \\
\hline L-Rhamnose & + & + & - & $\mathrm{d}$ & $-{ }^{*}$ & $\mathrm{ND}$ \\
\hline Maltose & - & - & + & $\mathrm{d}$ & $-*$ & ND \\
\hline Trehalose & - & + & + & + & $-*$ & ND \\
\hline Salicin & - & + & - & - & $-*$ & ND \\
\hline \multicolumn{7}{|l|}{ Utilization of: } \\
\hline Gluconate & - & + & + & + & $-*$ & $d \neq$ \\
\hline D-Mannose & - & + & + & + & $-{ }^{*}$ & $-\ddagger$ \\
\hline D-Xylose & + & + & + & + & $-*$ & $-末$ \\
\hline Maltose & - & + & + & + & $-*$ & +7 \\
\hline Trehalose & - & + & + & + & $+^{*}$ & -末 \\
\hline D-Sorbitol & - & - & + & + & $-*$ & ND \\
\hline Mannitol & - & + & + & + & $-*$ & $d \neq$ \\
\hline
\end{tabular}

${ }^{\star}$ Hauser et al. (2004).

$\dagger$ Yumoto et al. (2001).

\$Romanenko et al. (2005).

\$Hatayama et al. (2005)

Fluorescent pigments are not produced on King's medium B. The temperature, $\mathrm{pH}$ and $\mathrm{NaCl}$ ranges for growth are 5$42{ }^{\circ} \mathrm{C}$ (optimum, $30-37{ }^{\circ} \mathrm{C}$ ), $\mathrm{pH} \mathrm{5.0-9.0} \mathrm{(optimum,}$ $\mathrm{pH} 7.0-8.0$ ) and 0-2\% (optimum, 0-1\%). Good growth occurs on nutrient agar, MacConkey agar and Simmons' citrate agar. Casein, starch, DNA, Tween 80 and aesculin are hydrolysed, but gelatin, Tween 20 and carboxymethylcellulose are not hydrolysed. Positive for catalase, lysine decarboxylase, arginine dihydrolase and $\beta$-galactosidase acitivities. Negative for oxidase, arginine decarboxylase, ornithine decarboxylase, urease, phenylalanine deaminase, indole and hydrogen sulphide production, nitrate reduction and in the Voges-Proskauer reaction. Acid is produced from D-xylose, D-glucose, L-rhamnose and dextrin, but not from D-galactose, D-mannose, maltose, D-fructose, trehalose, D-mannitol, myo-inositol or salicin.
The following substrates are utilized (with no acid production): D-ribose, D-galactose, L-arabinose, sorbose, cellobiose, melezitose, melibiose, aesculin and amygdalin. Lactose, sucrose, maltose, D-fructose, trehalose, raffinose, Dmannose, turanose, glycerol, D-erythritol, D-arabitol, Dmannitol, sorbitol, D-xylitol, adonitol, myo-inositol, inulin, salicin, $N$-acetylglucosamine, gluconate, acetate and methyl $\alpha$-glucoside are not utilized. Sensitive to streptomycin, penicillin G, ampicillin, chloramphenicol, erythromycin, tetracycline, ofloxacin, amoxicillin, cefamezin, rifampicin, gentamicin, ceftazidime, kanamycin, carbenicillin and polymyxin $\mathrm{B}$, but resistant to vancomycin. DNA G $+\mathrm{C}$ content is $55.2 \mathrm{~mol} \%$. The fatty acid pattern is shown in Table 1.

The type strain, $\mathrm{HR} 2^{\mathrm{T}} \quad\left(=\mathrm{KCTC} \quad 22129^{\mathrm{T}}=\mathrm{CGMCC}\right.$ $1.6858^{\mathrm{T}}$ ), was isolated from a desert soil sample collected from the Taklimaken Desert in Xinjiang Province, China.

\section{Acknowledgements}

We thank the Chinese National Natural Science Foundation (30600001) and the Jiangsu Natural Sciences Foundation (BK2005422) for their financial support.

\section{References}

Anzai, Y., Kim, H., Park, J.-Y., Wakabayashi, H. \& Oyaizu, H. (2000). Phylogenetic affiliation of the pseudomonads based on 16S rRNA sequence. Int J Syst Evol Microbiol 50, 1563-1589.

Brosius, J., Palmer, J. L., Kennedy, J. P. \& Noller, H. F. (1978). Complete nucleotide sequence of $16 \mathrm{~S}$ ribosomal RNA gene from Escherichia coli. Proc Natl Acad Sci U S A 75, 4801-4805.

Cashion, P., Holder-Franklin, M. A., McCully, J. \& Franklin, M. (1997). A rapid method for the base ratio determination of bacterial DNA. Anal Biochem 81, 461-466.

Cui, X. L., Mao, P. H., Tseng, M., Li, W. J., Zhang, L. P., Xu, L. H. \& Jiang, C. L. (2001). Streptomonospora salina gen. nov., a new member of the family Nocardiopsaceae. Int J Syst Evol Microbiol 51, 357-363.

De Ley, J., Cattoir, H. \& Reynaerts, A. (1970). The quantitative measurement of DNA hybridization from renaturation rates. Eur $J$ Biochem 12, 133-142.

Escara, J. F. \& Hutton, J. R. (1980). Thermal stability and renaturation of DNA in dimethyl sulfoxide solutions: acceleration of renaturation rate. Biopolymers 19, 1315-1327.

Felsenstein, J. (1981). Evolutionary trees from DNA sequences: a maximum likelihood approach. J Mol Evol 17, 368-376.

Felsenstein, J. (1985). Confidence limits on phylogenies: an approach using the bootstrap. Evolution 39, 783-791.

Felsenstein, J. (1993). PHYLIP (phylogeny inference package), version 3.5c. Distributed by the author. Department of Genome Sciences, University of Washington, Seattle, USA.

Hatayama, K., Kawai, S., Shoun, H., Ueda, Y. \& Nakamura, A. (2005). Pseudomonas azotifigens sp. nov., a novel nitrogen-fixing bacterium isolated from a compost pile. Int J Syst Evol Microbiol 55, 1539-1544.

Hauser, E., Kämpfer, P. \& Busse, H.-J. (2004). Pseudomonas psychrotolerans sp. nov. Int J Syst Evol Microbiol 54, 1633-1637.

Huß, V. A. R., Festl, H. \& Schleifer, K. H. (1983). Studies on the spectrophotometric determination of DNA hybridization from renaturation rates. Syst Appl Microbiol 4, 184-192. 
Jahnke, K. D. (1992). BASIC computer program for evaluation of spectroscopic DNA renaturation data from GILFORD SYSTEM 2600 spectrophotometer on a PC/XT/AT type personal computer. J Microbiol Methods 15, 61-73.

Kersters, K., Ludwig, W., Vancanneyt, M., De Vos, P., Gillis, M. \& Schleifer, K.-H. (1996). Recent changes in the classification of the pseudomonads: an overview. Syst Appl Microbiol 19, 465-477.

Kimura, M. (1980). A simple method for estimating evolutionary rates of base substitutions through comparative studies of nucleotide sequence. J Mol Evol 16, 111-120.

Kimura, M. (1983). The Neutral Theory of Molecular Evolution. Cambridge: Cambridge University Press.

King, E. O., Ward, M. K. \& Rainey, D. E. (1954). Two simple media for the demonstration of pyocyanin and fluorescein. J Lab Clin Med 44, 301-307.

Kumar, S., Tamura, K., Jakobsen, I.-B. \& Nei, M. (2001). MEGA2: molecular evolutionary genetics analysis software. Bioinformatics 17, 1244-1245.

Manaia, C. M. \& Moore, E. R. B. (2002). Pseudomonas thermotolerans sp. nov., a thermotolerant species of the genus Pseudomonas sensu stricto. Int J Syst Evol Microbiol 52, 2203-2209.

Oyaizu, H. \& Komagata, K. (1983). Grouping of Pseudomonas species on the basis of cellular fatty acid composition and the quinone system with special reference to the existence of 3-hydroxy fatty acids. J Gen Appl Microbiol 29, 17-40.

Palleroni, N. J. (1984). Genus I. Pseudomonas Migula 1894. In Bergey's Manual of Systematic Bacteriology, vol. 1, pp. 141-199. Edited by N. R. Krieg \& J. G. Holt. Baltimore: Williams \& Wilkins.

Park, M., Ryu, S. H., Thi Vu, T.-H., Ro, H.-S., Yun, P.-Y. \& Jeon, C. O. (2007). Flavobacterium defluvii sp. nov., isolated from activated sludge. Int J Syst Evol Microbiol 57, 233-237.

Romanenko, L. A., Uchino, M., Falsen, E., Frolova, G. M., Zhukova, N. V. \& Mikhailov, V. V. (2005). Pseudomonas pachastrellae sp. nov., isolated from a marine sponge. Int J Syst Evol Microbiol 55, 919-924.
Saitou, N. \& Nei, M. (1987). The neighbor-joining method: a new method for reconstructing phylogenetic trees. Mol Biol Evol 4, 406-425.

Sasser, M. (1990). Identification of bacteria by gas chromatography of cellular fatty acids. USFCC Newsl 20, 16.

Smibert, R. M. \& Krieg, N. R. (1994). Phenotypic characterization. In Methods for General and Molecular Bacteriology, pp. 607-654. Edited by P. Gerhardt, R. G. E. Murray, W. A. Wood \& N. R. Krieg. Washington, DC: American Society for Microbiology.

Stackebrandt, E., Frederiksen, W., Garrity, G. M., Grimont, P. A. D., Kämpfer, P., Maiden, M. C. J., Nesme, X., Rosselló-Mora, R., Swings, J. \& other authors (2002). Report of the ad hoc committee for the reevaluation of the species definition in bacteriology. Int J Syst Evol Microbiol 52, 1043-1047.

Thompson, J. D., Gibson, T. J., Plewniak, F., Jeanmougin, F. \& Higgins, D. G. (1997). The CLUSTAL_X windows interface: flexible strategies for multiple sequence alignment aided by quality analysis tools. Nucleic Acids Res 25, 4876-4888.

Xu, P., Li, W.-J., Tang, S.-K., Zhang, Y.-O., Chen, G.-Z., Chen, H.-H., Xu, L.-H. \& Jiang, C.-L. (2005). Naxibacter alkalitolerans gen. nov., sp. nov., a novel member of the family 'Oxalobacteraceae' isolated from China. Int J Syst Evol Microbiol 55, 1149-1153.

Yamaguchi, S. \& Yokoe, M. (2000). A novel protein-deamidating enzyme from Chryseobacterium proteolyticum sp. nov., a newly isolated bacterium from soil. Appl Environ Microbiol 66, 3337-3343.

Yoon, J.-H., Kim, H., Kim, S.-B., Kim, H.-J., Kim, W. Y., Lee, S. T., Goodfellow, M. \& Park, Y.-H. (1996). Identification of Saccharomonospora strains by the use of genomic DNA fragments and rRNA gene probes. Int J Syst Bacteriol 46, 502-505.

Yumoto, I., Yamazaki, K., Hishinuma, M., Nodasaka, Y., Suemori, A., Nakajima, K., Inoue, N. \& Kawasaki, K. (2001). Pseudomonas alcaliphila sp. nov., a novel facultatively psychrophilic alkaliphile isolated from seawater. Int J Syst Evol Microbiol 51, 349-355.

Zhou, Y., Dong, J., Wang, X., Huang, X., Zhang, K.-Y., Zhang, Y.-Q., Guo, Y.-F., Lai, R. \& Li, W.-J. (2007). Chryseobacterium flavum sp. nov., isolated from a polluted soil. Int J Syst Evol Microbiol 57, 1765-1769. 